Beacons Mountain Scheme. The Trust continuod to provide bursaries for residential courses in the field sciences at the field study centres of tho Field Studies Council, and bursaries in 1964 wore given to 72 people, of whom 42 attended courses in England and Walos and 30 courses in Scotland. Members of 43 societies received such help. A second grant of $\$ 5,000$ was made towards tho field studies centro at Kindrogan, Strathardle, Perthshire, while grantis were again made to local archaeological societies affiliated to the Council of British Archaoology under the arrangement first made in 1958. The British Astronomical Association was again supported in its work among amateurs by subsidizing courses, and the grant of $£ 500$ from the Royal Meteorological Society was usod in 1964 to assist the Socioty to defray the cost of eight courses arranged by its Field Studies Committee.

\title{
NATURAL GAS FOR BRITAIN
}

$\mathrm{A}^{\mathrm{T}}$ a time whon the Government is exhorting tho gas and other major industries concerned with natural fuel resources to give a forward boost to coal mining by contracting an annual intake of half a million tons of coal or more, it is interesting to turn to a recent publication by the Gas Council which would appear to underline its present and future policy and intentions in no uncortain terms (Natural Gas for Britain, pp. 36. Tho Gas Council, 4-5 (Krosvenor Place, London, S.W.1; A.pril 1965). This is the story of the Gas Council's scheme for importation and utilization of natural gas from Algeria, a scheme which is now a fait accompli. In the words of Sir Henry Jones, chairman of the Gas Council: "Organization on a massive scale was required to combine, in a continuous supply operation, the activities of tho natural gas producers at Hassi R'Mel in the Sahara, the liquefaction plant at Arzew, tho ocean methane carriers, the Canvey terminal and the pipeline for the distribution to as far north as Leeds and Manchostor. All this had boen achievod within three years of the Minister's approval in November 1961 of the Gas Council's schomo to import methane from Algeria". Tho Methane Princess carried tho first commercial cargo of liquid methane to Britain, arriving at Canvey Island on October 12, 1964. About this time hor sister ship, Methane Progress, left the jetty at Arzew with the next cargo to complete the first round of a regular service, designed to deliver 700,000 tons of Algerian liquefied methane per arnum at Canvey; at this rate it is equivalent to 10 por cent of Britain's gas supply.

This publication provides a vivid and well-illustrated a,ccount of the rolatively short history of the Gas Council's enterprise in harnessing this new souree of power for Britain. It describes the initial role of the Methane Pioneer in experimental voyages made between the Gulf of Mexico and Canvey Island in 1959.60 ; the first $e x$ perimental load of liquefied natural gas actually arrivod at Canvey on February 20, 1959. A section "The U.K.-Algerian Project" outlines the seheme as a wholo, from production at Hassi R'Mel, pipeline via Rolizan to Arzew, tho liquefaction plant at Arzow, truns-shipment to Canvey, re-gasification and storage plant at Canvoy, thence onward distribution of the gas to tho various Area Boards by the methane grid serving London, Reading, Hitchin, Dunstable, Birmingham, Sheffield, Manchester and Leeds. Further sections are devoted to "Sahnran Seat of Operations" at Hassi R'Mel with its intricate systom of gas linos and gas-condensate storage tanks; to the spocialized design and equipment of the tankers involved in ocean transport-both Methane Princess and Methane Progress have a carrying capacity of 12,200 tons of liquid methane, equivalent in dimensions to a crude-oil tanker of 28,000 tons, and each cost $£ 4 \cdot 75$ million, roughly doublo that of a crude-oil tanker of the same dimensions; to the Canvey Island terminal with its unloading gear, pipes coated with ice as the tanker discharges her cargo, and complox array of pipework connected with the liquid-methane storago tanks and other units. "Britain's Methane Pipoline" is described in somo detail; the main pipoline is 18 in. outside diameter, branch lines ranging from 65 in. to $14 \mathrm{in}$, according to anticipated load requirements; this grid system distributes 90 million $\mathrm{ft}^{8}{ }^{3}$ of gas per day at a calorific valus of 1,100 B.Th.U./ft. ${ }^{3}$, about double the heating value at which town gas is normally supplied.

It is in the final soction of this booklet, "Gas Industry's New Horizons", that we discern the hopes and intentions of the Gas Council for the fiuturo. "This progress reflects the big change-over to hydrocarbon oils and gases which by 1968 will have reduced the industry's uso of coal to 40 por cent of gas production." It is pointed out that the Minister of Power in February 1964, in answer to a Parliamentary question, gave the following figures of comparative capital costs of moking gas and electricity por unit of installod capacity: electricity generation: atomic, coal-fired and oil-fired power stations, $£ 97, £ 34$ and $£ 32$ per $\mathrm{kW}$ respectively; gas making: oil reforming, $£ 8$ per $\mathrm{kW}$ equivalent. Prospects of obtaining new supplies of natural gas in future are promising. "Vast reserves lie fallow or are flared off as waste in areas more distant than Algeria which have been commercially inaccossible for want of sufficiently economic means of liquefaction and ocean transport. But the position is changing. An offer . . . to supply natural gas from Nigoria is currently being studied by the Gas Council". The possibilities of utilizing natural-gas resources nearer home are also envisaged; Dutch gas from Groningen, and, of course, the at prosent unknown but much-publicized potentialitins of the British area of the North Sea continental shelf. The Times, in its principal leading articlo appearing shortly after tho first arrival of the Methane Princess at Canvey in Oetober last year, remarked: "On a genorally sombre economic horizon, the future for gas is a rare, bright glow". There could scarcely be a more fitting commont on the facts as now disclosod by this informative booklet, nor on the pionoer work of the Gas Couneil and all concernod in bringing about this re-vitalization of the gas industry in Britain.

\section{SCHOOL BIOLOGY EXAMINATION SYLLABUSES}

$I^{N}$ a paper presented to a conference arranged by the Jnint Biology Committee in November 1964, L. C. Comber drew some general conclusions from new exum. ination syllabuses in biology which had been produced over the past two years (Biology and Human Affairs, 30, No. 2; Spring 1965). 'They are:

(1) Room hus beon found for some modom material and greater biochemical detail is more specifically asked 